\title{
Capital as Power and the Corporatisation of Education
}

\author{
Hanna Kivisto \\ PhD Candidate \\ School of Education \\ University of Technology, Sydney, Australia \\ Hanna.h.kivisto@gmail.com
}

This paper is a postprint of an article published by Critical Studies in Education (first posted on June 13, 2016 as doi: 10.1080/17508487.2016.1186707, available online at http://dx.doi.org/10.1080/17508487.2016.1186707).

\begin{abstract}
Building on the definition of critical education residing in the crossroads of cultural politics and political economy, this theoretical article offers an inquiry into the intersection between critical education research and the central ritual of contemporary capitalism - capitalisation. This article outlines four current approaches in education research literature to the corporatisation of education. This article argues that the approaches must rely implicitly on one of the two major theories of capitalism: modern neoclassical economics or Marxist political economy, even when the approaches are built on cultural and sociological arguments. Without an explicit engagement with the concept of capital and capitalisation, the approaches risk appearing theoretically weak and reliant on moral assumptions. In this sense, critical education literature would be strengthened by engagement with international political economy (IPE) literature. This article proposes to redress this lacuna in the literature by mobilising Jonathan Nitzan's and Shimson Bichler's theory of capital as power to better understand the corporatisation of education.
\end{abstract}

Keywords: capital as power, capitalisation, political economy of education, corporate education reform, neoliberalism, capitalism

\section{Introduction}

Opening up the education sector to capital accumulation is among the leading forces shaping public education (Lipman, 2015; Ball, 2012). At the same time, capitalism and its price system have 
extended to virtually every corner of the world to the point that we can think of the world as an interconnected 'market civilisation' (Gill, 1995). The central institutions of this civilisational order are the capitalised state and corporation, the international price system and various markets for goods and services. However, curiously the questions related to capitalism as it is understood by dominant investors are almost completely left out from mainstream education research, where - as Ball (2012, p.139) reminds us - profit and money tend to be secondary to ideas, practices and abstractions. Ball (2012) explicitly points out the current lacuna in the literature by reminding us that:

[W]e have neither the language and concepts nor the methods or techniques appropriate for researching neo-liberal practices. These developments and changes in education policy ... have outrun the current purview of our research agenda and we need to adapt and adjust what it is we consider research problems in order to catch up. ... In particular we must begin to draw upon forms of business and financial analysis, or to put it another way, we must "follow the money".

There is a growing and important body of work that analyses education corporations and their impact on education policy and practice, but this work focuses mainly on policy sociology and cultural criticism. As capitalism is the central social relation of critical education, this article argues that research into the corporatisation of education would be strengthened by researching how and why education corporations operate when they move into a previously not-for-profit sector with the lowest global market capitalisation index of major economic sectors (Hutter, 2015).

Building on Saltman's (2012, p.680) definition of critical education residing in the crossroads of cultural politics and political economy, this article argues for engagement with the defining component of contemporary capitalism - capitalisation - and mobilises Nitzan \& Bichler's emerging theory of political economy, called capital as power, to the field of education. First, adapting and building on Saltman's (2014) categorisation of the 'politics' in education, I will map the current mainstream approaches to the corporatisation of education in the education literature by dividing them into four approaches: neoliberal, liberal-paternalist, cultural resistance and the Marxistrevolutionary approach. For each approach I will briefly describe their main assumptions on the link between the economy and education, and contend that we need engagement with international political economy (IPE) to make sense of a changing educational landscape. Second, taking into account the substantial growth in global capitalisation in the last part of the twentieth century, I will offer the capital as power approach as a potentially powerful fifth approach to understand and research the corporatisation of education.

\section{Approaches to the Corporatisation of Education}

\section{The neoliberal approach}

In the neoliberal approach, education has three functions: first and foremost, education is a catalyst for economic growth in an equal opportunity society, thus requiring the monitoring of individual performance; second, education is a business sector unto itself; and third, education is a site of 'failure' which needs to transform in order to address a crisis, whether it is economic, natural or political (on the recovery function of education, see Slater, 2015). 
The challenges of the neoliberal approach in education have been widely recorded by critical education researchers in the last years. My criticism below draws from this work and focuses on two main notions put forward by the neoliberal approach. First, the approach sees education as a politically neutral act that takes place in an atomistic society and second, it relies on the modern neoclassical economics modelling to justify education policy. I will address both of these points below.

Education as a catalyst for economic growth relies on macro-level modelling of incentives and outcomes and thus needs measurable and quantifiable data in order for its success or failure to be assessed. (Ball, 2012, calls this a regime of numbers through which surveillance can be exercised. See also Ozga, 2009 and Lynch, 2015). This quantifiable data is underpinned by the notion of an atomistic society where the playing field is level and education a politically neutral act.

The 'failures' of the education system are attributed to inadequate governance due to 'imperfect monitoring and weak accountability in public systems' which can be alleviated by 'the competitive forces of school choice or by closer external monitoring of education outcomes', even if this can lead to 'wasteful signalling efforts on the part of schools and teachers' (Gradstein et al., 2005, p. 130). A report by the Organization for Economic Cooperation and Development (OECD) Universal Basic Skills - What Countries Stand to Gain (2015) considers the main problem with education to be 'the economic output that is lost because of poor education policies and practices' (OECD, 2015, p. 9). Economic growth is assumed to benefit everyone, and not harm anyone in the society, for example through the loss of access to farmland or raw materials. The OECD report recommends placing high value on education and expecting high standards from each student with no excuses for underperformance, but most importantly it recommends monitoring and improving the performance of underperforming teachers. The argument follows in the footsteps of the Reagan administration's report Nation at Risk: The Imperative for Educational Reform (1983) on the perceived failure of US schools by attributing structural macro-economic problems to a lack of educational productivity and thereby shifting the responsibility for national economic competitiveness onto education (Luke, 1998, p. 311).

In the neoliberal approach to the corporatisation of education, voters are assumed to be identical consumers who make rational choices in the education market. Market efficiency is achieved by treating educational institutions as providers of private service, instituting merit pay for highperforming teachers and monitoring the quantifiable outcomes. The OECD report also points out that the $10 \%$ of most disadvantaged students in Shanghai 'outperform' the $10 \%$ most advantaged students elsewhere and concludes that 'poverty isn't destiny. No one can afford to be complacent' (OECD, 2015, p. 13). According to this approach, an individual's standardised testing outcome comes down to the individual and the effort they are willing to make in their schooling. Since whatever divisive lines society might have can be overcome by individual capability, education acts as a screening and signalling mechanism that places high-performing individuals at the top of the labour force or as owners of institutions (Saltman, 2014).

Neoliberal education is informed, by definition, by neoclassical economic theory, which in turn relies on two assumptions that are relevant for education. First, the screening role of education is connected to marginal productivity theory and production function which determine the value of an individual's contribution to the production process by how much the market is willing to pay them. In other words, the compensation that an individual receives from his or her employment is directly translatable to the value that the individual adds to the market. Because every compensation is assumed to be just, the high-earning executive presumably adds quantifiably more value than his or her less earning counterparts. The theory thus assumes that high-earning individuals possess human 
qualities so rare and above anyone else in society that those abilities rightfully become the source of their wealth (Di Muzio, 2015a).Education and its screening role are thus crucial in selecting and signalling their innate superior skill set.

The second core assumption of the neoliberal approach to the corporatisation of education is the 1:1 resemblance between neoclassical economic theory and the reality in which education takes place. The approach assumes that under perfect market competition equilibrium market prices are established and for-profit education corporations are hence price-takers, meaning they cannot set prices themselves In the neoliberal approach to the corporatisation of education, for-profit education services cannot then be priced higher than the market can pay However, research into the price-setting behaviour of companies to be cost-focused instead of responding to demand (see, for example, Park, Rayner and D'Arcy, 2010; Fabiani et al., 2007).

\section{The liberal-paternalist approach}

The liberal view of education rejects the idea of reducing education solely to a business opportunity or training a national workforce. However, while the liberal view of education does express the distaste for outright corporatisation of schooling, it considers this to follow from the 'retreat of the state' after the neoliberal turn in the 1970s and 1980s (Strange, 1994). This duality model suggests that the state and the market are neutral and separate spheres with a clear demarcation between them and with different histories, methods and goals. The sphere of identity, citizenship education and the politics of representation inside the accepted canon belong to the sphere of education, whereas the workings of corporate capitalism or corporations are not topics education should concern itself with. The liberal-paternalist approach towards the corporatisation of education can be hence characterised as a 'nit-Piketty critique' of the corporatisation of education: Much like Thomas Piketty's (2014) bestselling work on economic inequality, the approach considers the system to be fundamentally benign but in need of better regulation of corporations or international financial institutions to be more inclusive. Despite the liberal distaste of outright neoliberal corporatisation of education, it is also worth noting the nodal points in the liberal-paternalist approach which create opportunities for profit: expanding access to education (charter schools, off-shore franchise university campuses or consultancies creating new policies), education technology companies providing new 'disruptive technologies' and 'learning solutions', testing companies providing and administering the necessary measurement of teacher and student performance and the list goes on.

This approach has two problematic points: First, under the guise of presumed universal valueneutrality, the approach assumes that the 'non-ideological' and (economically, if not always culturally) liberal Western education to be the sole induction to the global capitalism and thusly to individual and national prosperity. According to the liberal-paternalist approach, education is one of the key vehicles of human progress through acquiring and adapting to the cultural canon (Saltman, 2014) - in short, education is a civilising mission which can provide the opportunity for a country to join the global production chain or for an individual to grow their future income through acquiring necessary knowledge, values and skills. Relying on liberal politics, the liberal-paternalist approach to education considers the spread of liberal capitalism as an inherent public good. Indeed, much in the same way as international financial organisations are considered in critical political economy literature as neo-imperial vehicles for assimilation by uplifting (non-Western) states through cultural conversion (see, for example, Hobson, 2013, pp. 1048-50), the liberal-paternalist mission is to close the 'achievement gap' through more and better education (Saltman, 2012; 2014). The approach relies on the assumption of universal value-neutrality that gives it the permission to act as a 
benevolent force that, in fact, provides a basis for neo-imperialist politics. For example, the for-profit educational rebuilding in Iraq was contracted to a company 'to normalize basic education in Iraq following a conflict' and to incorporate 'democratic practices in the classroom' and develop students' critical-thinking skills (The Economist April 3, 2003, quoted in Saltman, 2006, p. 54) - in other words, to act as an uplifting force through cultural conversion. In addition to creating economic opportunities for the individual, national public education acts as an accommodating agent to the culture that is often defined and dominated by white professional knowledge (Saltman, 2007; 2014) and one of education's key aims becomes to define, impose and deliver a 'core of common values' to migrants and minorities alike (Friedman, 2002, p. 96).

Second, much like in the neoliberal approach, the playing field is considered level for all students and society treated as an a-historical, cohesive, just and inevitable community where individuals can overcome class inequalities through hard work. Social investments in the form of expanding access to education are preferred in the place of passive and direct income transfers, as higher test scores in standardised tests are expected to translate to a higher income through the screening role of education. By assuming that access to this politically 'neutral' education is the only or among the leading causes of structural inequality globally and individually, this approach seeks to eradicate inequality through expanding access to education. In other words, the social, ethnic or geographical 'achievement gap', measured by standardised testing, needs to be closed by expanding access to educational resources, premised on the notion that more education provides inclusion to global capitalism, both nationally and individually (Saltman, 2015). This was the approach taken by the United Nations (UN) in the Millennium Development Goals (MDGs) where achieving universal primary education by 2015 by expanding access to education was one of the key goals. However, as the international development assistance budget from the global North to the global South does not exceed money flowing out from the South in the form of debt payments (World Bank, 2015), unbeneficial trade agreements and illicit financial flows such as tax evasion (Kar \& Spanjers, 2014), it is not probable that increasing assistance for education without addressing the general mechanisms of global corporate capitalism would produce a substantially different education outcome. As long as we analyse education through inequalities in educational attainment and consider this happening in a vacuum, Sustainable Development Goals (SDGs), the successors to MDGs, promise little change.

\section{The cultural resistance approach}

Bowles and Gintis' (1976) seminal work on the link between education and economy introduced reproduction theory and its correspondence principle to education. Reproduction theory, as outlined by Bowles and Gintis, rested on two principles: the labour theory of value and the required education for creating public consent for the exploitation of the vast majority of workers to benefit the wealthy few (Saltman, 2015, p. 228). The early work on the theory was criticised for its overly deterministic view of schooling and the lack of focus on agency (see, for example, Giroux, 1983) leading to treating schools and education institutions as 'black boxes' (see Apple, 1979). As a counter-reaction to reproduction theory, from the 1980s onwards more emphasis was placed on the ideological content of schooling, the cultural critique and the politics of representation instead of macro-level critique of capitalism. One could argue that this cultural turn in critical education research is still the dominant perspective from which the corporatisation of education is analysed. Although there is a considerable body of work in the field addressing responses to neoliberalism and the restructuring of public services in general, few have engaged in an analysis of capitalism. 
In the foreword of his book on private education 'solutions' and the potential end of state education in its 'welfare' form, Ball (2012, p. xiii) warns the reader that his aim is to 'provide tools and methods for thinking about neoliberalism rather than telling you what I think you should think about it', even though it is 'fashionable to do so', as 'we as yet know little about 'what is really going on'. What I call the cultural resistance approach to the corporatisation of education recognises the gross inequalities and structural oppression in a society, but suggests that the main debate should focus on the new policy spaces, subjectivities and teacher performativity that neoliberalism, understood as an ideological perspective or a set of political discourses (see, for example, Ball \& Olmedo, 2013) forces on education policy and practice. The role of critical education is thus to interrupt existing power relations through exposing these discourses and practices and through building the rhetoric of resistance to neoliberalism writ large. Below I will argue for two main weaknesses of the approach, which are: (1) The approach is not underpinned by an explicit theory of political economy and relies on moral assumptions in relation to public vs. private debate, and (2) The approach is based on state-market duality, which positions the literature as defending the public space from private profit interests and is thus unable to analyse the state as part of the logic of accumulation.

Although critical education is greatly influenced by Karl Marx and the various formulations of neoMarxist theory, drawing on concepts such as Bourdieu's habitus (Bourdieu, 1986) cultural marginalisation can be considered independent of, and primary to, material conditions (see, for example, Aronowitz \& Giroux, 1989). According to this approach, social justice in education can be thus decontextualised from the wider economy. The central tenets of neoliberalism and capital accumulation are assumed to be known and employed with no clear articulation of a theory informing the understanding of political economy. Thus the descriptions of concrete policy changes or resistance take the centre stage. While the cultural resistance approach does engage in the emergence of corporations in the education space, the main focus appears to be on cultural analysis, the social ontology of neoliberalism, subjectivities that neoliberal practices produce or on how neoliberal ideology is translated into practices and policies (see, for example, Ball \& Junemann, 2012; Hogan, 2015; Robertson, Bonal and Dale, 2002; Olmedo, 2013; Burch, 2009; Reckhow, 2013; Picciano and Spring, 2012).

While I agree that policy sociology and ideology criticism are central research areas for critical education in the twenty-first century, I argue that approaching the corporatisation of education solely as a 'new moral system' (Ball \& Olmedo, 2013) or an 'ideological perspective' (Olmedo, 2013) without an analytical engagement with theories of political economy does not capture the actual workings of contemporary capitalism. For example, a strategy paper by Education International, a global federation of teacher unions, A Global Response to Education Corporations (2014) sets out a timely project for advocating against 'privatisation in and of education'. The paper struggles to move beyond fairly simplistic statements as 'profiting off of poor families is unacceptable' (p.4) or resisting corporations that 'exploit workers in for profit schools' (p.7). While not intended to be an academic publication, the paper does not offer an analysis of the source of profit or, put differently, a theory of value. In the case of the latter statement in the strategy paper, the reader might be correct to assume that the paper subscribes to Marx's labour theory of value, where the capitalist's profits are made by paying less to workers than what their output is worth. The labour theory of value and the subsequent exploitation of workers is the fundamental reason for Marx to resist capitalist ownership of production. With no further analysis, the strategy paper's position in relation to exploited teachers faces significant challenges when we remind ourselves that for Marx, the productive and exploited labour force existed only in an industrial setting. The moral position against 'diverting money intended for children's education' to corporations' (p. 4) would benefit from an analysis of the basis of the economy where neoliberalism takes place and a deeper analysis of the creation and 
distribution of surplus. As the source of profit (or surplus) either justifies the capitalist income (neoclassical economics) or the reason to resist it (Marxist political economy), the paper fails to provide any ultimate reason for resisting the corporatisation of education beyond an unsubstantiated moral argument.

The cultural approach is tied to the demarcation between 'state' and 'markets', where education needs to be defended against corporations 'moving in' to a space where they have not operated before. Patricia Burch's (2009) excellent analysis on privatisation within the US public education system, especially as it was advanced by the No Child Left Behind policy, describes the on-going changes as a 'weak government and strong market' (p. 62) and that the two separate spheres 'have become more closely linked' (p.1). This duality also influences network analysis when applied to the corporatisation of education (Au and Ferrare, 2015; Ball \& Junnemann, 2012; Hogan, 2015; Picciano and Spring, 2012). Ball and Junemann (2012) focus on 'nodal actors' or 'boundary spanners', both individuals and organisations working on the surface of the boundary between the state and the market. This starting point means that the job of critical education is to push corporations out of the space where they do not belong (that of state) or, at least, to limit their influence. What the statemarket duality excludes from critical consideration are two, and I argue essential, elements. First, the state is subject to the same logic of capitalisation and private accumulation as corporations through the state's national debt which is owned by private lending institutions and generates earnings for their shareholders. Put shortly, the state is a capitalised entity and the claims for future income streams generated by the entity (in the state's case, by collecting taxes, fees and fines) can be bought and sold, and are owned by a small minority of humanity (Di Muzio 2015a, 2015b; see also Hager, 2014). Second, corporate practices in public space, including education, are mainly advanced through national and international policy, as demonstrated, among others, by Robertson, Bonal and Dale (2002). Stephen Gill (1995) has called this 'disciplinary neoliberalism', where the state and the market logic are largely indistinguishable in the service of capital accumulation and where the demarcation line between the two is only artificial (for an account in colonial history, see, for example, Stern, 2012).

\section{The Marxist-revolutionary approach}

The Marxist-revolutionary approach to the corporatisation of education is rooted in the emergence of Marxist thought in the field in the 1970s and 1980s, which shifted the emphasis towards Marxist theory as a framework for socialist movement-building against capitalism and state-sponsored oppression (Gottesman, 2013). The approach considers capitalist society to be organised by and for the elite, following Marx's understanding of the conflict between hegemonic tendencies in society that naturalise the unequal class relations and changes in the mode of production that generate and cause class conflicts (Apple, 1988, p. 231). The approach is hence explicitly based on Marxist political economy (Allman, 2010; McLaren and Jaramillo, 2010; Rikowski, 2001) and considers the transformation of social relations as the basis for social justice. However, as Nitzan (2015) and Nitzan \& Bichler (2009) point out, Marx was writing towards the end of the nineteenth century, before the exponential growth in corporate capitalisation. Finance and capitalisation, then, is only of secondary interest for Marxists, as the 'real' value is born in production (for a detailed discussion the discrepancy between 'real' and the financial value of capital in Marxist political economy, see Nitzan and Bichler, 2009, chapters 6 and 7). 
In Marx's writing, the grand theory of capitalism rests on socially necessary abstract labour time. However, labour values tell us very little about what really matters to the dominant owners of corporations in modern capitalism: the capitalisation of their assets on the stock and bond markets, which Marx dubbed 'fictitious capital' (Nitzan \& Bichler, 2009, p. 92). As a result, the Marxistrevolutionary approach to the corporatisation of education cannot explain the trajectory of financial markets and thus face 'the unpalatable choice of dismissing their movements as irrelevant, classifying them as "distortions" or simply surrendering to the bourgeois theory of corporate finance and injecting its neoclassical econometrics into their Marxist dialects' (Nitzan \& Bichler, 2009). It is this lack of political economy in education and the subsequent powerlessness to engage with twenty-first century corporate capitalism to which I now turn to explore.

\section{Capitalisation and the corporatisation of education}

As Ball $(2012$, p. xii) has pointed out, most education policy analysis is still locked into the nationstate, policy-as-government paradigm, but this is increasingly challenged by a growing number of works focused on the education corporation from the perspective of policy sociology and cultural analysis. However, if we take critical education at its own word as an open-ended project, instead of a fait accompli, it is only through understanding the origins of the system that produces the social injustice experienced by students and teachers that the system can be fundamentally challenged.

A quote, often attributed to John Kenneth Galbraith, advises that in order to argue with Milton Friedman, one just has to wait for him to say 'let us assume...' and then object to assuming anything that is not, in fact, correct. Above I have argued that in regards to the corporatisation of education, the discipline has not revisited its own assumptions but instead mostly relies implicitly on neoclassical or Marxist economics without fully investigating the explanatory power of these theories. In order to understand education's connection to the logic of accumulation, we need to understand twenty-first century capitalism and its central ritual, capitalisation.

Although capitalisation in its earliest form precedes capitalism, today it can understood as the process whereby a future flow of earnings is discounted into a present price and adjusted for some factor of risk (Di Muzio 2015b, p. 38). Put simply, market capitalisation is the total market value of a company's outstanding shares and is calculated by multiplying a company's outstanding shares by the current market price of one share. For example, if the share price of a company is $\$ 10$ and the company has 10 outstanding shares, the market capitalisation of the company is $10 \times 10=\$ 100$. The forward-looking dimension of market capitalisation is used by the investment community to estimate the value of the discounted cash flow that a company is expected to generate. Buying shares in a company, or capitalising it, translates then to owning a claim to a discounted future income stream. An emerging theory of political economy, called capital as power, understands capitalisation by dominant owners as the central ritual of contemporary capitalism that is intertwined at all levels of society from individuals (banks are effectively capitalising an individual's capacity to generate an income stream when giving out a loan) and companies to sovereign states (through their privately owned national debt) (for a detailed discussion, see Di Muzio, 2015a, 2015b; Nitzan and Bichler, 2009).

Former Hewlett-Packard chief executive officer Carly Fiorina announced her 2016 US Republican presidential bid in May 2015. As an outsider to politics, she said that her private-sector background sets her apart from other candidates, because, 'I understand how the economy actually works' 
(emphasis mine). Even while one might strongly disagree with her politics and her record in the business world, the argument touches upon a fundamental point that goes largely ignored in the education literature: none of the approaches outlined above explain the real world of capitalisation which is the central element in the of corporatisation of education.

A telling example of education corporations operating mostly in a newpace is that education has the lowest global spending-market capitalisation ratio of major economic sectors. In 2013, the global spending on education and training was $\$ 4.6$ trillion US dollars, but the combined market capitalisation of education corporations with capitalisation in excess of $\$ 500$ million US dollars was approximately $2 \%$ of total global spending. This is significantly different compared to healthcare or media and entertainment where the ratio is over $80 \%$ (Hutter, 2015). At the same time, the number of start-up companies in the education market has risen tenfold since 2008 (Hutter, 2015), and funding to private start-up education technology companies alone has grown $503 \%$ in the period from 2010 to 2014 (CB Insights, 2015). The sector is now considered profitable enough for niche education venture capital firms, such as LearnCapital, which was the fourth most active investor in private education technology companies in 2010-2015 (ibid.). According to one estimate, with data from a start-up database CrunchBase, over $\$ 4$ billion US dollars in total venture capital has been invested in education technology companies in 2015 (Watters, 2015). What we can expect, based on the sector's low spending-capitalisation ratio and the simultaneous growth in private start-up company investment are several initial public offerings (IPOs) during the next decade as the private start-up companies seek public listing after a period of innovation and growth (Chart 1).

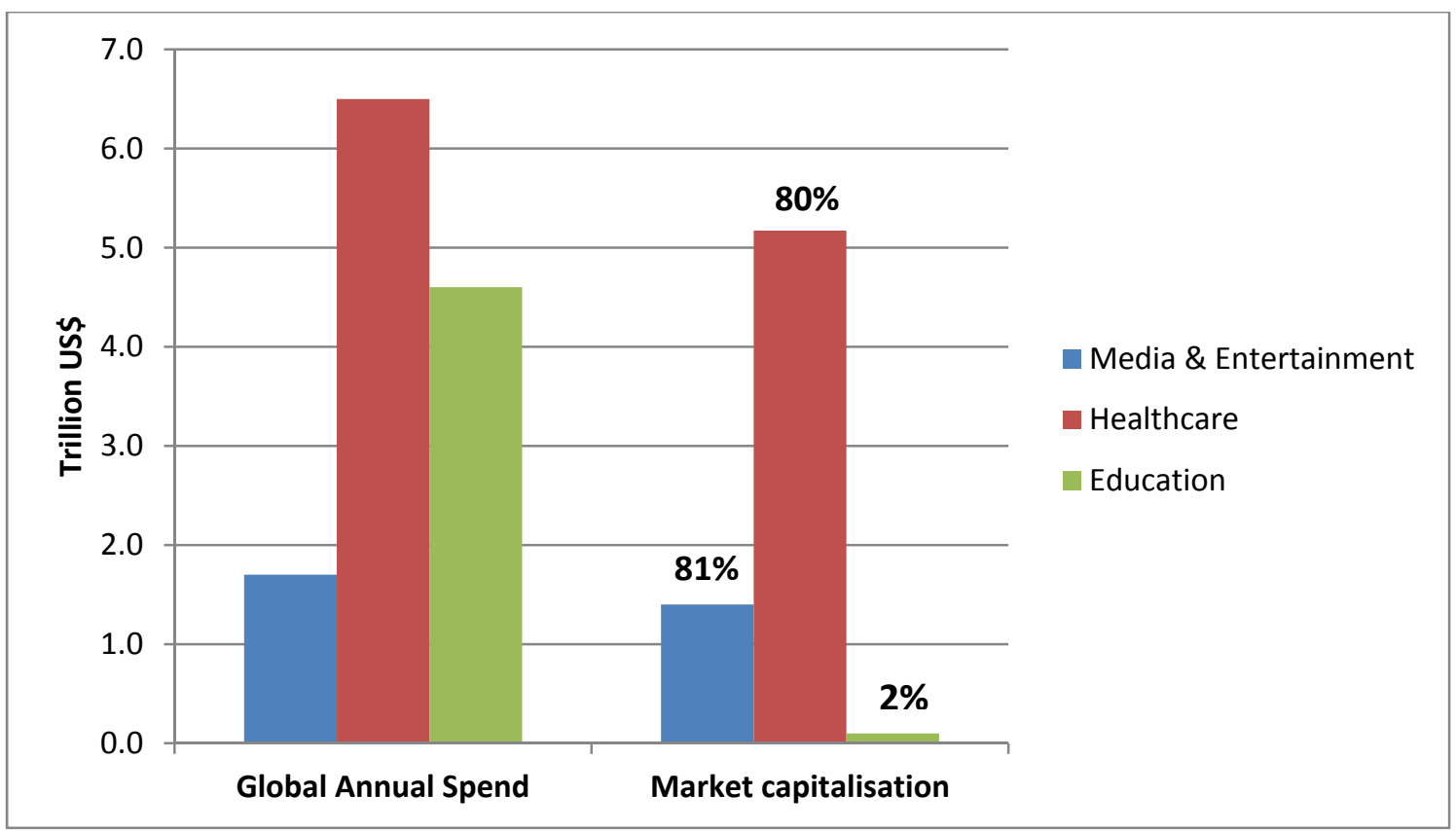

Chart 1. Total global annual spending and market capitalisation of companies with capitalisation in excess of US\$500M of some major economic sectors in 2013. (Data from Hutter, 2015).

The corporatisation of education is a potentially interesting case study of corporations establishing operations in a previously publicly funded sector, but this fundamental shift cannot be captured within the existing approaches in the education literature. I argue that the absence of engagement with capitalisation and the theoretical foundations to analyse capitalism compromise the 
transformative power that the discipline potentially has regarding the corporatisation of education, while simultaneously narrowing the scope of critical education to cultural politics or instrumental classroom literature.

\section{Capital as Power}

In an examination of world trade and its impact on education systems, Robertson, Bonal and Dale (2002) use the concepts of the fixity and motion of capital, and argue that for 'capital to continue accumulating, perpetual motion and points of fixity are necessary. At its very simplest, what this means is that to ensure its constant expansion, capital has to be mobile, seeking out new means and places to make profit.' (p. 474). The article does not define what is meant by 'capital', so the reader might assume it to be shorthand for money invested. However, there are only two major traditions that analytically define capital - neoclassical and Marxist, and neither of them define 'capital' as finance; both base their definitions in production.

For neoclassicals, capital stands for factors of production and it is a quantifiable and material entity. For instance, Di Muzio shows how this definition of capital is used in one of the leading economics textbooks: 'Capital "is the set of tools that workers use: the construction worker's crane, the accountant's calculator, and this author's personal computer" (Mankiw, 2009, p. 47, quoted in Di Muzio, 2015b, p. 35). In neoclassical economics, the distribution of surplus is justified by the unique productivity of capital goods, and this is where it gets interesting for critical education. A key concept in modern neoclassical economics is the production function, which relates the output to the amount of inputs, and justifies the distribution of resulting income based on the so-called contribution to output. The production function is supposed to demonstrate how each factor of production is rewarded according to its contribution to economic output (Di Muzio, 2015, 36), hence the high-earning investor or an executive supposedly adds more value to the market than, let's say, a public school teacher. However, as Nitzan and Bichler (2009, chapter 5) point out, the production function breaks apart when trying to demonstrate this empirically. Di Muzio offers a summary of the problematic nature of the production function:

The major problem is that to make this computation, we have to know the physical magnitude of labour, land and capital before we can determine output and therefore the distribution of income - that is, who deserves what based on their contribution. However, even if there was a clear and precise way to calculate the mathematically exact contribution from land and labour in modern finance, the value of capital goods is contingent on the income it generates. (Di Muzio, 2015b, p. 36) ${ }^{1}$

Without a working definition of capital and thus working production function, neoclassicals' unequal income from production is impossible to justify scientifically.

Karl Marx took into account class power, and argued that the only thing that could add value to nature to make commodities was human labour power. Because productive labour is the only source of value for Marxists, capitalists must pay workers less than the value they create if a surplus is to be achieved. Nitzan and Bichler (2009), even though sympathetic to the Marxist project, demonstrate that measuring labour values contained in a commodity is an impossible task. It is worth noting that Marx did write about capitalisation, but considered it purely fictitious:

\footnotetext{
${ }^{1}$ See also the Cambridge Capital Controversy (Cohen \& Harcourt, 2003).
} 
Everything appears turned upside down here, since no real prices and their real basis appear in this paper world, but only bullion, metal coin, notes, bills of exchange, securities. - - - (T)he entire process becomes unintelligible. (Marx, 1894, p.576, quoted in Nitzan, 2015, emphasis by Nitzan).

The two major traditions of political economy thus leave us with incorrect definitions of capital, far removed from how actual capitalists think of money, finance and investment. Should critical education research choose not to employ an explicit theory of capitalism, the reader has no choice but to assume that one of the major traditions is being used. In order to research the political economy of education, we should have a working theory that either justifies the distribution of surplus to capitalists (mainstream neoclassical economics through the production function) or the reason for a revolt against exploitation (exploitation of workers through unpaid labour). For Nitzan and Bichler, as well as the emerging capital as power school of thought, there is too much at stake not to consider an alternative theory of capitalism.

The capital as power approach was introduced to political economy by Jonathan Nitzan and Shimshon Bichler (2009). In the approach 'capital' is not a material entity found in production (capital goods or surplus dead labour) but a form of social power that is commodified as it is bought and sold in the financial markets as claims to future income like stocks and bonds. The key tenets of the capital as power approach are summarised in Table 1.

Because capital is not solely rooted in production, for Nitzan and Bichler capital-ism is not a historical mode of production, but a historical mode of power. This commodified social power is owned by a small minority of humanity, and its accumulation is measured in rising accumulation, registered in monetary units:

The capital-as-power perspective theorizes that the generation of earnings is not a simple matter of producing for the market, but a far broader power process that involves shaping and reshaping the global field of social reproduction and the wider conditions of existence. In essence, what gets capitalized is the corporation or state's power to affect social reproduction in such a way as to generate earnings faster than rivals. (Di Muzio, 2015b, p. 38)

In other words, the value of capital is not determined by production alone, as mainstream neoclassical economics or Marxist political economy would suggest.

\begin{tabular}{|c|c|c|}
\hline & $\begin{array}{l}\text { Modern economics: Neoclassical and } \\
\text { Marxist }\end{array}$ & Capital as Power \\
\hline Central ritual & $\begin{array}{l}\text { Manufacturing } \\
\text { Exchange }\end{array}$ & Capitalisation \\
\hline $\begin{array}{l}\text { Foundation of } \\
\text { economy }\end{array}$ & $\begin{array}{l}\text { - Modern neoclassical economics: } \\
\text { Exchange } \\
\text { - Marxist political economy: } \\
\text { - Production } \\
\text { - Both in the 'real' sphere of economy }\end{array}$ & Capital as power: Finance \\
\hline $\begin{array}{l}\text { Definition of } \\
\text { capital }\end{array}$ & $\begin{array}{l}\text { Dichotomy of capital: Real and } \\
\text { financial capital (real and nominal } \\
\text { spheres of economy) } \\
\text { Capital exists only as a measurable } \\
\text { physical unit }\end{array}$ & $\begin{array}{l}\text { - Capital exists only as social } \\
\text { power, and recorded in } \\
\text { pecuniary units } \\
\text { - No direct relation to physical } \\
\text { productivity }\end{array}$ \\
\hline
\end{tabular}




\begin{tabular}{|c|c|c|}
\hline & $\begin{array}{l}\text { - Financial value is a distortion of the } \\
\text { 'real' value of capital }\end{array}$ & \\
\hline Source of profit & $\begin{array}{l}\text { Production: } \\
\text { - Neoclassical economics: Individual } \\
\text { productivity of capital goods } \\
\text { (marginal theory of value) } \\
\text { - } \\
\text { Marxist political economy: Unpaid } \\
\text { surplus labour (labour theory of } \\
\text { value) }\end{array}$ & $\begin{array}{l}\text { Exclusion (power theory of value): } \\
\text { - Earnings delinked from } \\
\text { production - company books do } \\
\text { not capitalise the innovation, } \\
\text { but the patent/copyright } \\
\text { protecting it. }\end{array}$ \\
\hline $\begin{array}{l}\text { Definition of } \\
\text { accumulation }\end{array}$ & $\begin{array}{l}\text { Accumulating capital goods or dead surplus } \\
\text { labour? }\end{array}$ & $\begin{array}{l}\text { - Rising capitalisation relative to a } \\
\text { benchmark (such as S\&P500). } \\
\text { - Absentee ownership: The } \\
\text { augmentation of claims over } \\
\text { future streams of income over a } \\
\text { portfolio }\end{array}$ \\
\hline $\begin{array}{l}\text { Logic of } \\
\text { accumulation }\end{array}$ & Maximum accumulation & $\begin{array}{l}\text { Relative accumulation against a } \\
\text { benchmark }\end{array}$ \\
\hline Capitalism & Mode of production & Historical mode of power \\
\hline
\end{tabular}

Table 1. Key tenets of the capital as power approach (based on Nitzan and Bichler, 2009; Di Muzio 2015a, 2015b).

In this framework, accumulation, thus, is understood as rising capitalisation, such as growing bond yields and prices (depending on the position of the buyer/seller), increasing share prices and rising values for real estate and other investment products (Di Muzio, 2015b, 7). Corporate earnings are not theorised as a narrow offshoot of production (as is the case for neoclassicals and Marxists), but as the result of a broad power process exerted by corporations over the field of social reproduction. Put another way, to generate earnings, corporations aim to shape and reshape the terrain of social reproduction by exerting power over society. The level of capitalisation of the corporation is indication of its power to shape and reshape social order. It is for this reason that the capital as power approach argues that 'capital' is no material entity but differential commodified power measured in money. For example, when Apple is capitalised by investors, investors are not purchasing shares in Apple's power to merely produce iPhones as both neoclassicalists and Marxists would argue. Investors are purchasing shares in Apple's power to exclude others from using the products for free and the company's power to shape and reshape the terrain of social reproduction in their interests. As Nitzan and Bichler note:

The capitalist mode of power is counted in prices, and capitalization, working through the ever more encompassing price system, is the algorithm that constantly restructures and reshapes this order. Capitalization discounts a particular trajectory of expected future earnings. For any groups of capitalists - typically a corporation - the relative level and pattern of earnings denote differential power: the higher and more predictable these earnings are relative to those of other groups of companies, the greater the differential power of the corporation's owners. - - - When these earnings and their volatility are discounted into capital values, the power institutions and processes that underlie them become part of capital. And since capital is a vendible commodity, available for purchase and sale on the 
stock and bond markets, its relative value represents the commodification of power. (2009, p.

9, emphasis original)

There is more work to be done in showing how critical education could benefit from this approach, but the capital as power approach opens up new possibilities for theorising the link between education and private accumulation by the $1 \%$ or what Di Muzio (2015a) calls 'dominant owners'. For example, Robertson, Bonal and Dale (2002) define three ways that education is associated with the expansion of capital: through infrastructural support, social order and providing the system with legitimation. The authors point out that after GATS, education itself has become part of capital accumulation, instead of merely a means to an end. If we are to look at capitalism from the perspective where capitalisation is the central ritual of contemporary capitalism, we can argue that education is inherently tied to the logic of accumulation. States are capitalised entities, similar to corporations, through their national debts. Bearing in mind that capitalisation is always a risk adjusted claim on a future income stream, whether it is corporate earnings, a private individual's capacity to generate an income (usually through wage labour) or a state's capacity to collect taxes, fees and fines, we can see that private creditors of national debts are capitalising the state's increasing future income streams, in short, its expanded revenues through economic growth. As the human capital theory underpins a large part of national economic growth to upskilled workforce, we can argue that education has always been directly linked to private accumulation through the process of capitalisation. Capital as power could thus inform a fifth approach to the corporatisation of education where the basis of the economy is neither production nor exchange per se, but finance. Whereas corporate lobbying and special interest groups' impact on public policy is hardly news to anyone, capital as power first of all offers a theoretically sound approach for this research instead of implicit and unquestioned reliance on major theories of capital or moral perspectives, but it also opens up new research possibilities that earlier approaches are unable to scrutinise.

\section{Conclusion}

This article has argued that in order to understand and research corporate education reforms, critical education should indeed 'follow the money' and engage more rigorously with the fundamental tenets of corporate capitalism: finance and capitalisation. I have argued that the current education literature has only two choices when researching the political economy of education: It can either use neoclassical economics or Marxist political economy as the theoretical framework, or alternatively, analyse the corporatisation of education with little or no theoretical engagement with capitalism. This paper has shown that the capital as power framework is a radical new theory that argues for researching capitalism as it actually works and is understood by investors and capitalists. The theory is radical in the very meaning of the word: it questions the core assumptions of political economy by not suggesting revisions to existing theories but proposing a new way of researching capitalism.

As Nitzan and Bichler (2009) see capitalisation as the central ritual of contemporary capitalism, we can identify at least three possible future research questions. First, the ongoing privatisation, commodification and capitalisation of education in the form of increasingly multi-national corporations can be mapped using the capital as power framework. For example, how do these corporations set their prices and how are they creating inclusions and exclusions in the field of education? Are they price-takers, as mainstream economics would suggest, or are they price-makers, as the capital as power approach suggests? Second, and a subject of my future work, as capitalisation was invented long before the modern corporation, most sovereign states today are 
capitalised entities through their national debts. In this case, investors capitalise the safest investment in capitalism - the state's ability to enforce and collect taxes, fees and fines. As neoclassical growth theories assume that education is one of the key factors in generating national economic growth, education is inherently connected to the logic of accumulation, finance and capitalisation even outside corporate education reforms. Thus, when investors purchase government bonds, they are not only capitalising the state's ability to generate growing income streams in order to be repaid with interest at some future date, but they are also capitalising education policy. How the private capitalisation of the state through its national debt relates to education practices and policy should be high on our research agendas. Third, this national debt is often used as a justification for cutting back on social spending on education, as an excuse for austerity and alternatively, or sometimes combined, with increases in tuition fees. Particularly in the United States but increasingly in other countries as well, rising tuition fees lead to students coming out of higher education institutions with large debts with a part of their future incomes funnelled back to banks whose business model, in this case, is to capitalise on the students' ability to sell something, usually their labour, in exchange for an income. It is paramount for critical education to investigate this process by considering how banks and other financial institutions capitalise the future wages and salaries of students for the benefit of their shareholders.

Future work is required to explore how the capital as power approach can be best employed to analyse the corporatisation of education. However, as outlined here, the approach provides one possible theoretical starting point for a fifth research approach to education corporations. As Nitzan and Bichler (2009) remind us, their theory is not a theory of society, but a theory of capitalist practices. It cannot explain what actually goes on within the 'black box' of the classroom (Apple, 1979 , p. 26) or demonstrate how the effects of twenty-first century corporate capitalism are built within schools. What the capital as power approach can do, however, is offer a clear understanding of the corporatisation of education and more effectively situate critical education in the intersection of cultural politics and political economy. 


\section{References}

Allman, P. 2010. Critical Education against Global Capitalism. Karl Marx and Revolutionary Critical Education. Rotterdam: Sense.

Apple, M. 1979. Ideology and Curriculum. London: Routledge and Kegan Paul.

Apple, M. 1988. Standing on the Shoulders of Bowles and Gintis: Class Formation and Capitalist Schools. History of Education Quarterly, Vol. 28, No. 2, pp. 231-241.

Aronowitz, S. \& Giroux, H. 1989. Education Still Under Siege. Westport, CT: Bergin \& Garvey.

Au, W. \& Ferrare, J. 2015. Mapping corporate education reform: Power and policy networks in the neoliberal state. New York, NY: Routledge.

Ball, S. 2012. Global education Inc.: New policy networks and the neo-liberal imaginary. London: Routledge.

Ball, S. \& Junemann, C. 2012. Networks, New Governance and Education. Bristol, UK: The Policy Press. Bourdieu, P. 1986. The Forms of Capital. In Richardson, J. (Ed.) Handbook for Theory and Research for the Sociology of Education, pp. 46-58. New York, NY: Greenwood.

Bowles, S. \& Gintis, H. 1976. Schooling in capitalist America: Educational reform and the contradictions of economic life. New York, NY: Basic Books.

Burch, P. 2009. Hidden Markets: The New Education Privatization. London and New York, NY: Routledge.

CB Insights. 2015. Funding to VC-backed Education Technology Startups Grows 503\% over 5 Years. Retrieved December 9, 2015 from https://www.cbinsights.com/blog/ed-tech-funding-on-pacerecord-year/

Cohen, A. \& Harcourt, G. 2003. Whatever Happened to the Cambridge Capital Theory Controversies? Journal of Economic Perspectives, 17(1), pp. 199-214.

Di Muzio, T. 2015a. The 1\% and the Rest of Us: A Political Economy of Dominant Ownership. Zed Books: London.

Di Muzio, T. 2015b. Carbon Capitalism: Energy, Social Reproduction and World Order. London and New York: Rowman \& Littlefield.

Fabiani, S., Loupias, S. Monteiro Martins, F. And Sabbatini, R. 2007. Pricing Decisions in the Euro Area: How Firms Set Prices and Why. New York: Oxford University Press

Friedman, Milton. 2002 (1962). Capitalism and Freedom. Chicago: University of Chicago Press.

Gill, S. 1995. Globalisation, Market Civilisation \& Disciplinary Neoliberalism. Millennium (24)3, pp. 399-423

Giroux, H. 1983. Theory and resistance in education: A pedagogy for the opposition. South Hadley, MA: Bergin \& Garvey.

Gradstein, M.; Justman, M. \& Meier, V. 2005. The political economy of education: Implications for growth and inequality. Cambridge, MA: MIT Press. 
Gottesman, I. 2013. Socialist Revolution: Samuel Bowles, Herbert Gintis, and the Emergence of Marxist Thought in the Field of Education. Educational Studies 49, pp. 5-31.

Hager, S. 2014. What Happened to the Bondholding Class? Public Debt, Power and the Top One Per Cent. New Political Economy 19(2), pp. 155-182.

Hogan, A. 2015. Boundary spanners, network capital and the rise of edu-businesses: the case of News Corporation and its emerging education agenda. Critical Studies in Education 56(3), pp. 301314.

Hutter, R. 2015. Education is an outlier in market capitalisation. Retrieved December 2, 2015 from http://learncapital.com/education-is-an-outlier-in-market-capitalization/.

Kar, D. \& Spanjers, J. 2014. Illicit Financial Flows from Developing Countries: 2003-2012. Global Financial Integrity. Retrieved May 14, 2016 from http://www.gfintegrity.org/report/2014-globalreport-illicit-financial-flows-from-developing-countries-2003-2012/

Lipman, P. 2015. Capitalizing on crisis: venture philanthropy's colonial project to remake urban education. Critical Studies in Education, Vol. 56(2), 241-258.

Luke, A. 1998. Getting over method: Literacy teaching as work in "new times". Language Arts 75(4), pp. 305-313.

Lynch, K. 2015. Control by numbers: new managerialism and ranking in higher education. Critical Studies in Education, Vol. 56(2), pp. 190 -207.

McLaren, P. \& Jaramillo, N. 2010. Not Neo-Marxist, Not Post-Marxist, Not Marxian, Not Autonomist Marxism: Reflections on a Revolutionary (Marxist) Critical Pedagogy. Cultural Studies $\leftrightarrow$ Critical Methodologies, 10(3), pp. 251-262

Nitzan, J. 2015 (31 March). Capital Accumulation: Fiction and Reality. Presentation at Université du Québec à Montréal [Video file]. Retrieved June 30, 2015 from https://www.youtube.com/watch?v=4S3Ws35KOVQ.

Nitzan, J. \& Bichler, S. 2009. Capital as Power: A Study of Order and Creorder. New York, NY: Routledge.

OECD / Hanushek, E. \& Woessmann, L. 2015. Universal Basic Skills: What Countries Stand to Gain. Paris: OECD Publishing.

Olmedo, A. 2013. Policy-makers, market advocates and edu-businesses: New and renewed players in the Spanish education policy arena. Journal of Education Policy, 28(1), pp. 55-76.

Ozga, J. 2009. Governing Education through Data in England: From Regulation to Self-Evaluation. Journal of Education Policy, 24(2), pp. 149-162.

Park, A., Rayner, V. and D'Arcy, P. 2010. Price-setting behaviour - Insights from Australian Firms. Reserve Bank of Australia Bulletin, June Quarter 2010. Retrieved from http://www.rba.gov.au/publications/bulletin/2010/jun/bu-0610-2a.html.

Peters, M., Paraskeva, J. \& Besley, T. (Eds.) 2015. The Global Financial Crisis and Educational Restructuring. New York, NY: Peter Lang.

Picciano, A. \& Spring, J. The great American education-industrial complex: Ideology, technology, and profit. New York, NY: Routledge. 
Piketty, T. 2014. Capital in the twenty-first century: The dynamics of inequality, wealth, and growth. (Translated from French by Arthur Goldhammer). Cambridge, MA: The Belknap Press of Harvard University Press.

Reckhow, S. 2013. Follow the money: How foundation dollars change public school politics. New York, NY: Oxford University Press.

Rikowski, G. 2001. The battle in Seattle: Its significance for education. London: Tufnell Press.

Robertson, S., Bonal, X. \& Dale, R. 2002. GATS and the Education Service Industry: The Politics of Scale and Global Reterritorialization. Comparative Education Review, 46(4), pp. 472-496.

Saltman, K. 2006. Creative Associates International: Corporate Education and "Democracy Promotion" in Iraq. Review of Education, Pedagogy and Cultural Studies, 28(1), pp. 25-65.

Saltman, K. 2007. Capitalizing on disaster: Taking and breaking public schools. Boulder and London: Paradigm Publishers.

Saltman, K. 2012. Why Henry Giroux's Democratic Pedagogy Is Crucial for Confronting Failed Corporate School Reform and How Liberals like Ravitch and Darling-Hammond Are Making Things Worse. Policy Futures in Education 10(6): pp. 674-687.

Saltman, K. 2014. The Politics of Education: A Critical Introduction. Paradigm Publishers: Boulder and London.

Saltman, K. 2015. The New Two-Tiered Education System in the United States: Expanding and commodifying poverty and inequality. In S. N. Haymes, M. V. De Haymes, \& R. J. Miller (Eds.), The Routledge Handbook of Poverty in the United States. New York, NY: Routledge, pp. 226-231.

Slater, G. 2015. Education as recovery: neoliberalism, school reform, and the politics of crisis. Journal of Education Policy 30(1): pp. 1-20.

Stern, P. 2012. The company-state: Corporate sovereignty and the early modern foundations of the British empire in India. Oxford \& New York, NY: Oxford University Press.

Strange, S. 1994. States and Markets. London and New York, NY: Pinter.

The National Commission on Excellence in Education. 1983. A Nation at Risk: The Imperative for Educational Reform: A report to the Nation and the Secretary of Education. Washington, DC: United States Department of Education.

The World Bank. 2015. International Debt Statistics 2015. Washington, DC: World Bank Group.

Watters, A. 2015. The Politics of Education Technology. A blog post retrieved December 9, 2015 from http://2015trends.hackeducation.com/politics.html. 